\title{
A five year record of high-frequency in situ measurements of non-methane hydrocarbons at Mace Head, Ireland
}

\author{
A. Grant ${ }^{1}$, E. L. Yates ${ }^{1}$, P. G. Simmonds ${ }^{1}$, R. G. Derwent ${ }^{2}$, A. J. Manning ${ }^{3}$, D. Young ${ }^{1}$, D. E. Shallcross ${ }^{1}$, and \\ S. O'Doherty ${ }^{1}$ \\ ${ }^{1}$ Atmospheric Chemistry Research Group, University of Bristol, Bristol, UK \\ ${ }^{2}$ rdscientific, Newbury, Berkshire, UK \\ ${ }^{3}$ Met Office, FitzRoy Road, Exeter, Devon, UK
}

Received: 4 January 2011 - Published in Atmos. Meas. Tech. Discuss.: 7 February 2011

Revised: 12 May 2011 - Accepted: 12 May 2011 - Published: 24 May 2011

\begin{abstract}
Continuous high-frequency in situ measurements of a range of non-methane hydrocarbons have been made at Mace Head since January 2005. Mace Head is a background Northern Hemispheric site situated on the eastern edge of the Atlantic. Five year measurements (2005-2009) of six $\mathrm{C}_{2}-\mathrm{C}_{5}$ non-methane hydrocarbons have been separated into baseline Northern Hemispheric and European polluted air masses, among other sectors. Seasonal cycles in baseline Northern Hemispheric air masses and European polluted air masses arriving at Mace Head have been studied. Baseline air masses show a broad summer minima between June and September for shorter lived species, longer lived species show summer minima in July/August. All species displayed a winter maxima in February. European air masses showed baseline elevated mole fractions for all non-methane hydrocarbons. Largest elevations (of up to $360 \mathrm{ppt}$ for ethane maxima) from baseline data were observed in winter maxima, with smaller elevations observed during the summer. Analysis of temporal trends using the Mann-Kendall test showed small $\left(<6 \% \mathrm{yr}^{-1}\right)$ but statistically significant decreases in the butanes and $i$-pentane between 2005 and 2009 in European air. No significant trends were found for any species in baseline air.
\end{abstract}

\section{Introduction}

The role of non-methane hydrocarbons (NMHCs) in the production of tropospheric ozone was first reported by HaagenSmit and Fox (1956). NMHC as a classification includes alkanes, alkenes, alkynes and aromatic species, all of which

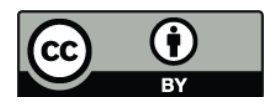

Correspondence to: S. O'Doherty (s.odoherty@bristol.ac.uk) form ozone by reaction with the hydroxyl radical $(\mathrm{OH})$ in the presence of nitrogen oxides $\left(\mathrm{NO}_{\mathrm{x}}\right.$ where $\left.\mathrm{NO}_{\mathrm{x}}=\mathrm{NO}+\mathrm{NO}_{2}\right)$. $\mathrm{NO}_{\mathrm{x}}$, which is emitted mainly by fossil fuel combustion, is an essential component in the ozone formation cycle, in the absence of $\mathrm{NO}_{\mathrm{x}}$ ozone cannot be formed in the troposphere. Tropospheric ozone is a harmful pollutant which has negative effects on human health and vegetation. Background tropospheric ozone in the Northern Hemisphere has been reported to be increasing by $0.49 \mathrm{ppb} \mathrm{yr}^{-1}$ with a current background Northern Hemispheric mole fraction of $\sim 42 \mathrm{ppb}$ (Simmonds et al., 2004). Oltmans et al. (2006) also reported an increase of $13 \% / d e c a d e$ from 1987 to 2005 at Mace Head. To assess if recent increases in tropospheric ozone can be linked to changes in NMHC mole fractions one needs to analyse a long-term record of NMHC measurements. These measurements must be made at a background location to minimise the effects of local pollution on data and enable effective analyses of long-term trends and seasonal cycles. It is difficult to elucidate trends and seasonal cycles from urban measurement records because of almost continually elevated NMHC mole fractions from local pollution.

This paper reports on continuous high-frequency measurements of a range of NMHCs conducted at Mace Head from January 2005 to December 2009. These measurements extend those reported by Yates et al. (2010) from January 2005 to December 2006. This longer dataset enables the assessment of long-term trends of NMHC species. NMHCs reported include ethane, propane, $\mathrm{i}$ and $n$-butane, $i$ and $n$ pentane. These data provide information on long-term trends and seasonal cycles of NMHCs in background Northern Hemispheric air. Individual measurements are sorted using a Lagrangian dispersion model to separate clean background air from regionally polluted European air masses and those transported from southerly latitudes. Yearly and seasonal

Published by Copernicus Publications on behalf of the European Geosciences Union. 


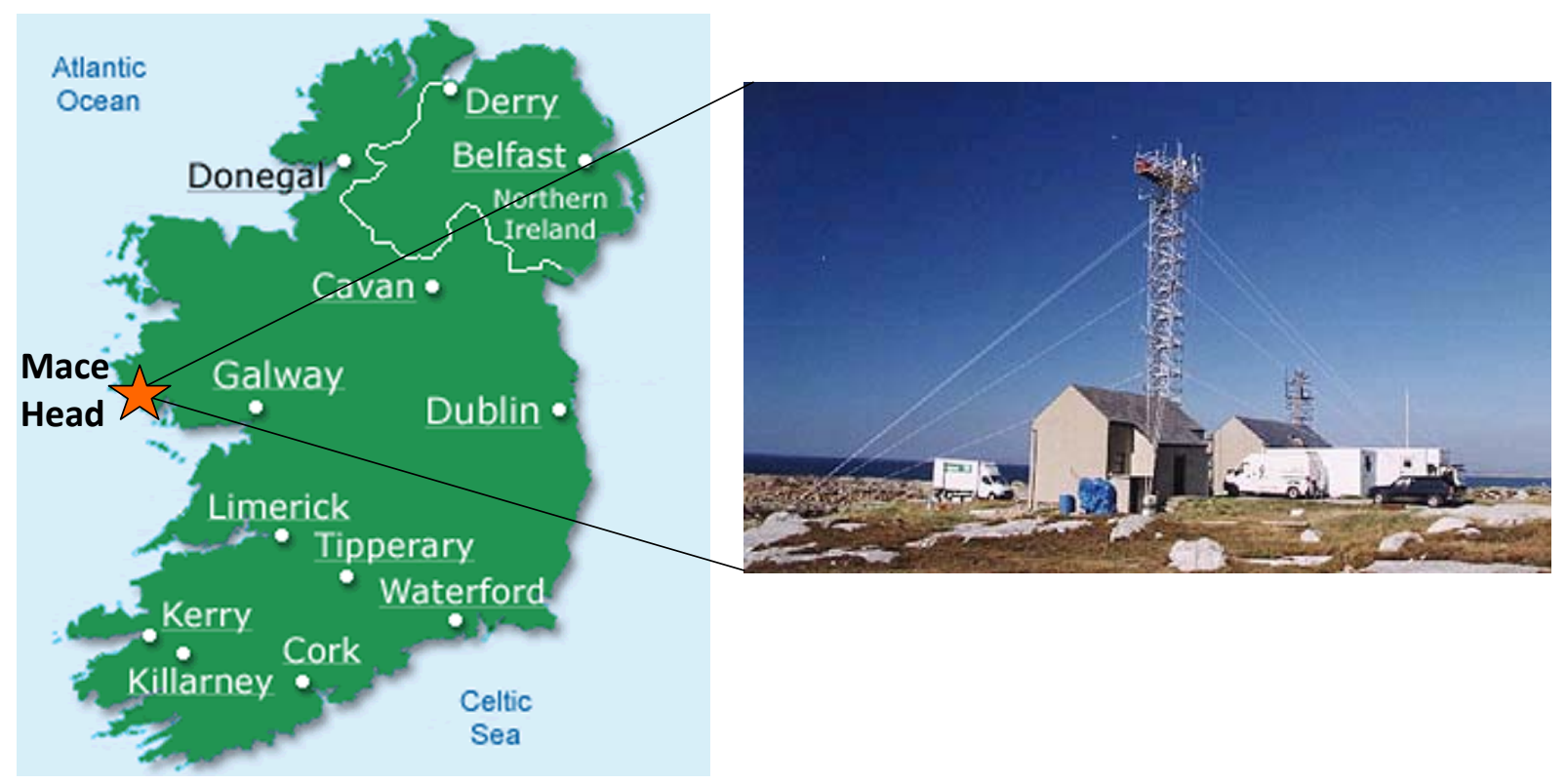

Fig. 1. Location of the Mace Head research station on the west coast of Ireland.

trends are assessed and variations and anomalies in baseline air masses accounted for. The aim of this paper is to report the long-term, high frequency NMHC measurements made at Mace Head, further publications are in preparation which will include detailed and comprehensive interpretation of the data presented here.

\section{Experimental}

\subsection{Measurement location}

The Mace Head atmospheric research station $\left(53^{\circ} 20^{\prime} \mathrm{N}\right.$, $9^{\circ} 54^{\prime} \mathrm{W}$ ) is situated on the west coast of Ireland (Fig. 1). At the station, numerous ambient air measurements are made as part of the Advanced Global Atmospheric Gases Experiment (AGAGE) (Cunnold et al., 1997; Prinn et al., 2000) and the Global Atmospheric Watch network (GAW). It is one of only a few clean background western European stations, thus providing an essential baseline input for inter-comparisons with continental Europe, whilst also acting as a baseline site representative of Northern Hemispheric air. Prevailing winds from the west to southwest sector bring clean background air to the site. Polluted European air masses as well as tropical maritime air masses cross the site periodically. Mace Head is therefore uniquely positioned for resolving these air masses and for comparative studies of their constitution. Galway is the closest city, with a population of 72000 , sitting $50 \mathrm{~km}$ to the east whilst the area immediately surrounding Mace Head is very sparsely populated providing very low local anthropogenic emissions. The sample inlet is located $10 \mathrm{~m}$ inland from the shoreline, sampling at $10 \mathrm{~m}$ above sea level, through stainless steel lines attached to a meteorological tower. The area surrounding Mace Head is generally wet and boggy with areas of exposed rock (Dimmer et al., 2001).

\subsection{Instrumentation}

The measurement system couples an Agilent 6890 gas chromatograph (GC)/5973 mass selective detector (MSD) with a low-temperature, cryogen-free pre-concentration system, the Medusa (Miller et al., 2008). This self-contained cryogenic technology is essential due to the inaccessibility of field locations and difficulty of obtaining consumables such as liquid nitrogen. The ambient air sample inlet is situated $10 \mathrm{~m}$ up a $20 \mathrm{~m}$ high tower. Ambient air is flushed through an inlet line, made of $1 / 4^{\prime \prime}$ instrument-grade stainless steel tubing, a portion of this air is delivered to the Medusa inlet where a backpressure regulator controls the sample pressure at 1.5 bar and vents at $\sim 21 \mathrm{~min}^{-1}$ (Miller et al., 2008). Analysis of each 21 sample of ambient air was alternated with analysis 21 of reference gas (also delivered to the Medusa at $1.5 \mathrm{bar}$ ) to determine and correct for short term instrumental drift, resulting in 12 fully calibrated air samples per day. At the heart of the Medusa is a Polycold "Cryotiger" (Polycold division of Brooks Automation, Petaluma, CA) cold end which maintains a minimum trapping temperature of $-175^{\circ} \mathrm{C}$. This cold end conductively cools a copper baseplate which supports two traps to about $-165^{\circ} \mathrm{C}$. By using aluminium standoffs of limited thermal conductivity to connect the traps to the cold head, each trap can independently be heated resistively to any temperature from $-165^{\circ} \mathrm{C}$ to $+200{ }^{\circ} \mathrm{C}$ or more, while the baseplate remains cold. The use of two traps with very wide programmable temperatures ranges, coupled with the 
Table 1. Measurement parameters of sample precision and limit of detection.

\begin{tabular}{lrr}
\hline Species & $\begin{array}{r}\text { Limit of } \\
\text { Precision } \\
\%\end{array}$ & $\begin{array}{r}\text { Detection } \\
\text { ppt }\end{array}$ \\
\hline ethane & $1-2$ & 2.8 \\
propane & $0.6-2$ & 1.2 \\
$i$-butane & $2-5$ & 3.0 \\
$n$-butane & 3 & 0.9 \\
$i$-pentane & $3-10$ & 1.2 \\
$n$-pentane & $3-6$ & 1.0 \\
\hline
\end{tabular}

development of appropriate trap absorbents, permits the desired analytes from 21 air samples to be effectively separated from more-abundant gases in the air matrix that would otherwise interfere with chromatographic separation or mass spectrometric detection. A detailed description of Medusa sampling is presented in Miller et al. (2008). NMHC measurements from another AGAGE Medusa GC-MS instrument situated at the Scripps institution of Oceanography, USA have been reported by Mühle et al. (2007).

The instrument is controlled by GCWerks ${ }^{\mathrm{TM}}$ custom designed software (http://gcwerks.com/) which automates all the instrument parameters (valves, trap temperatures, MSD etc.), displays chromatograms, performs peak integration and gives graphical and tabulated displays of all results. For maximum sensitivity in routine field monitoring the MSD is operated in Selective Ion Monitoring (SIM) mode. This cycles the MSD through selected target and qualifier ion masses during the specified windows of elution in the chromatogram.

In this study, hydrocarbon measurements carried out at Mace Head since 2005 are reported. The Medusa-GCMS which measures NMHCs was originally developed to make high frequency in situ measurements for the determination of atmospheric lifetimes and emissions of various compounds related to the Montreal and Kyoto Protocols. The Medusa measures a wide range of halocarbons, NMHCs and sulfur compounds involved in ozone depletion and climate forcing (Miller et al., 2008). A network of five Medusa systems are located at remote field stations around the world (Mace Head, Ireland; Ragged Point, Barbados; Cape Grim, Tasmania; Cape Mataula, American Samoa; and Trinidad Head, California) operated by the Advanced Global Atmospheric Gases Experiment (AGAGE) since 2003 providing 12 in situ ambient measurements per day (http://agage.eas. gatech.edu/). The Medusa-GCMS at Mace Head initially measured the NMHC ethane. The suite of NMHCs measured was extended in 2005 by Yates et al. (2010) to also include: propane, $n$-butane, $i$-butane, $n$-pentane and $i$-pentane. Modifications made to the Medusa-GCMS to extend the number of compounds measured are detailed in Yates et al. (2010). NMHC measurements are limited in number in order to leave the Medusa-GCMS AGAGE measurements of CFCs, PFCs, HFCs, HCFCs and $\mathrm{SF}_{6}$ uncompromised. It is essential that any additional measurements do not interfere with measurements of AGAGE core species. Alkene measurements are recorded using this system, but research shows that there is production of alkene artefacts from the Nafion drier (pentene and butenes) (Boudries et al., 1994). Since the Medusa-GCMS uses two Nafion driers to dry air samples prior to pre-concentration alkene measurements have not been attempted with this system.

Ethane was detected with the MSD in selected ion monitoring mode (SIM) using a target ion, $\mathrm{C}_{2} \mathrm{H}_{2}^{+}(\mathrm{m} / \mathrm{z} 26)$, propane $\mathrm{C}_{3} \mathrm{H}_{5}^{+}(\mathrm{m} / \mathrm{z} 41), i$-butane $\mathrm{C}_{3} \mathrm{H}_{6}^{+}(\mathrm{m} / \mathrm{z} 42), n$-butane, $i$-pentane and $n$-pentane $\mathrm{C}_{3} \mathrm{H}_{7}^{+}(\mathrm{m} / \mathrm{z} 43)$. Blanks and laboratory air were measured weekly to check for contamination of the instruments working environment. Blank samples are carrier gas trapped as a normal air or standard sample and run under standard instrument conditions. Blanks were $<0.5 \%$ of the average baseline peak size for ethane, propane and $n$ butane and $<2 \%$ of the average peak size for $i$-butane and the pentanes. Instrument precision is an indicator of the detectors response over a period of time. Precision was calculated from the standard-standard ratios of concurrent standard analyses. Table 1 shows precisions and limits of detection of the range of NHMCs measured where the limit of detection is calculated as three times of the mean blank.

\subsubsection{Calibration}

Working standards (quaternary standards) are prepared by compressing background ambient air at Mace Head, into 351 electropolished stainless steel canisters (Essex Cryogenics, Missouri, USA) using a modified oil-free compressor (SA-3, RIX California, USA). This ensures that NMHC mole fractions in quaternary standards are close in concentration to air sample values at Mace Head minimising sample matrix non-linearities. The quaternary standards are used to bracket each air measurement in an attempt to minimise detector response non-linearities. In addition tertiary standards (air filled at Trinidad Head, California and calibrated for halocarbons at Scripps Institution of Oceanography (SIO) against their primary calibration scales) are analysed weekly against the quaternary standards. The quaternary working gases are calibrated over the course of their use in the field by analyses against the tertiary standards. The NMHC quaternary calibration is linked by analysis of tertiary standards against an NMHC primary standard (O'Doherty et al., 2004). The NMHC primary standard was made by accurate volumetric dilution of a ppb mole fraction synthetic standard (Apel Reimer USA, cylinder CC144868) to ppt mole fractions, to mimic ambient NMHC mole fractions observed at this background site. The Apel-Reimer standard was diluted by a ratio of 12.9 as detailed in Yates et al. (2010). The NMHC primary calibration standard has concentrations of $\mathrm{C}_{2}-\mathrm{C}_{5}$ alkanes in 

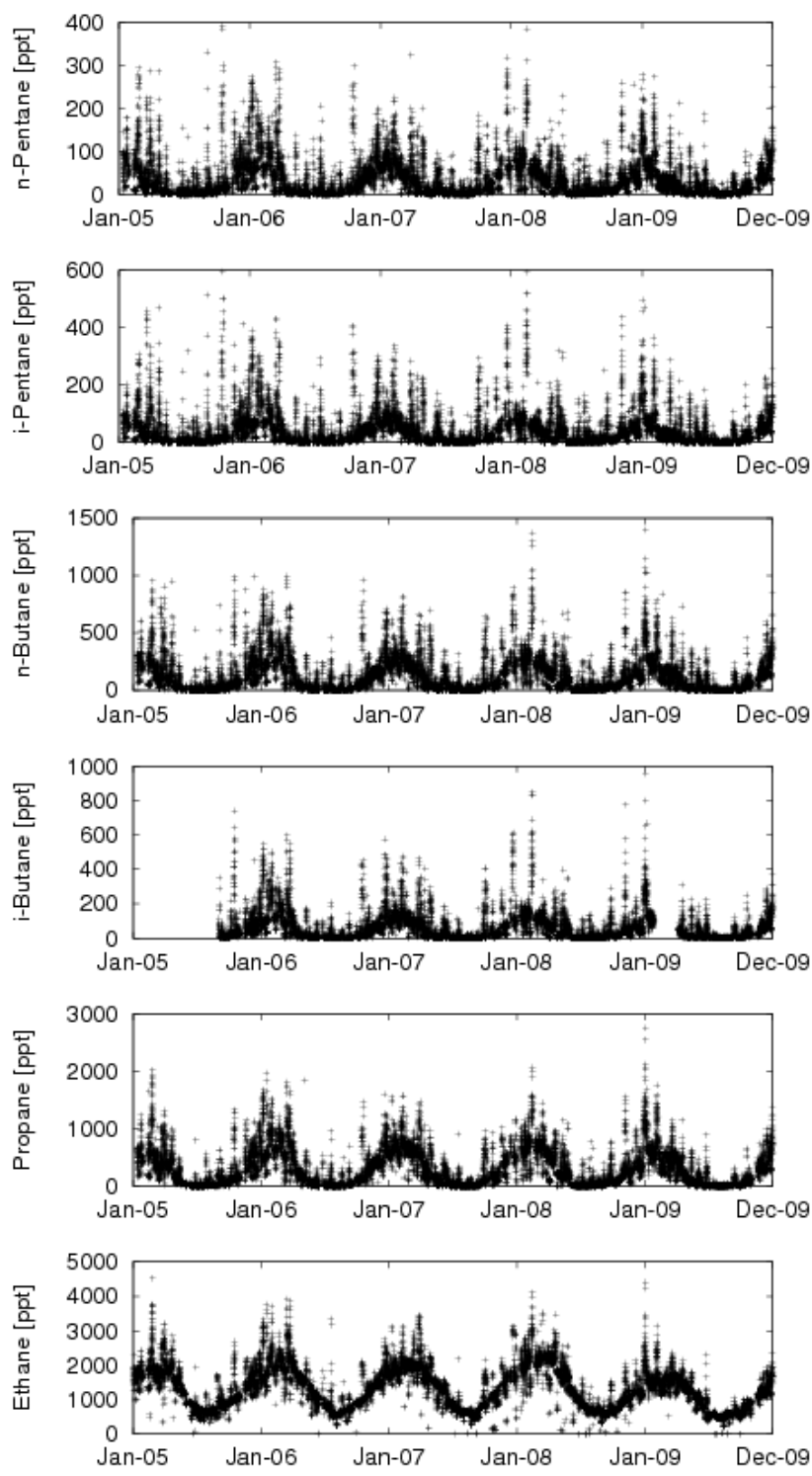

Fig. 2. All data for $\mathrm{C}_{2}-\mathrm{C}_{5}$ alkanes from January 2005 until December 2009 .

ppt of 908 for ethane, 813 for propane, 736 for $n$-butane, 372 for $i$-butane 591 for $n$-pentane and 556 for $i$-pentane. Analysis of this NMHC primary standard against each new tertiary standard from SIO enabled application of NMHC mole fractions measured on the Medusa. This primary standard was assigned values based on a comparison made against the NPL-scale, standard D45 7238. This found our primary standard to be higher by $3 \%, 5 \%, 5 \%, 20 \%$ and $25 \%$ for ethane, propane, $n$-butane, $i$-pentane and $n$-pentane respectively, whilst $i$-butane was $2 \%$ lower than the NPL-scale in our primary standard.

\section{Results}

NMHC species measured by the Medusa-GCMS include; ethane, propane, $i$-butane, $n$-butane, $i$-pentane and $n$ pentane. NMHC data from January 2005 to December 2009 are shown in Fig. 2. These data were sorted into air mass origins using the NAME Lagrangian atmospheric dispersion model (Jones et al., 2007; Ryall and Maryon, 1998) using the technique described in Manning et al. (2011). This classified measurements into different sector types: baseline (westerly or north westerly airflow shown in Fig. 3), European polluted, southerly transport, mixed (when air was from a variety of sectors), and local (times when there were low wind speeds and stable air so sources and sinks in the local region would significantly impact the observations). Only air masses classified as baseline, European and southerly transported will be discussed in detail in this paper. These three air masses display distinctly different concentration patterns and baseline and European data form the large majority ( $>60 \%)$ of air masses measured at Mace Head.

To calculate air mass sectors the NAME dispersion model is run backwards to estimate the recent history (12 days) of the air en-route to Mace Head. Baseline mole fractions are defined as those which have not been influenced by significant emissions within the previous 12 days of travel en-route to Mace Head, i.e. those that are well mixed and representative of the mid-latitude Northern Hemisphere background mole fractions. European air masses are those which have travelled from mainland Europe, the UK and Ireland. Further details of this sorting method can be found in Manning et al. (2011).

\subsection{Long term trends and elevations}

Many studies have reported marked decreases in the mole fractions of NMHCs measured in mainland Europe and the UK between the 1990s and 2000 (Derwent et al., 2003; Dollard et al., 2007; Dore et al., 2007; Solberg et al., 2002). This decrease in observed mole fractions was brought about by a reduction in hydrocarbon emissions resulting from the implementation of the Geneva Protocol to the Convention on Long-Range Transboundary Air Pollution CLRTAP (UN ECE, 1991, http://www.unece.org/env/lrtap/vola h1.htm) with the aim of reducing emissions of ozone precursors. The Gothenburg multi-pollutant Protocol (UN ECE, 1999, http://www.unece.org/env/lrtap/multi_h1.htm) was setup eight years later with the same aim. Reductions were primarily made in the transport sector through improvements in engine systems and installation of 3-way catalysts, reducing emissions of both VOC and $\mathrm{NO}_{\mathrm{x}}$. Solberg et al. (2002) reported decreases in VOC concentrations of $20-50 \%$ from 1993-2000 at two central European EMEP sites. However, in the same report an absence of trend was found at two rural Finnish sites, one of which (Pallas) is reported in Table 2 (Hakola et al., 2006). 
Table 2. Trends of hydrocarbons $\left(\% \mathrm{yr}^{-1}\right)$ measured at Mace Head in baseline and European air masses from 2005-2009 calculated using the Mann-Kendall test.

\begin{tabular}{|c|c|c|c|c|c|c|c|}
\hline \multicolumn{5}{|c|}{ Comparable data } & \multicolumn{3}{|c|}{ Other data } \\
\hline & Our & & $\begin{array}{l}\text { von Schneidemesser } \\
\text { et al. (2010) }\end{array}$ & $\begin{array}{l}\text { von Schneidemesser } \\
\text { et al. (2010) }\end{array}$ & $\begin{array}{l}\text { Sauvage } \\
\text { et al. (2009) }\end{array}$ & $\begin{array}{l}\text { Dollard } \\
\text { et al. (2007) }\end{array}$ & $\begin{array}{l}\text { Hakola } \\
\text { et al. (2006) }\end{array}$ \\
\hline$\% \mathrm{yr}^{-1}$ & $\begin{array}{l}\text { NH Baseline } \\
2005-2009\end{array}$ & $\begin{array}{l}\text { European } \\
\text { 2005-2009 }\end{array}$ & $\begin{array}{l}\text { Rural UK } \\
1998-2008\end{array}$ & $\begin{array}{l}\text { Rural Germany } \\
1998-2008\end{array}$ & $\begin{array}{l}\text { Rural France } \\
\text { 1997-2006 }\end{array}$ & $\begin{array}{l}\text { Rural UK } \\
1995-2001\end{array}$ & $\begin{array}{l}\text { Subarctic } \\
1994-2003\end{array}$ \\
\hline Ethane & $<1$ & $<-1$ & 0 & 0 & $<1$ & -7 & 1.6 \\
\hline Propane & 6 & -1 & $-3^{+}$ & $-2^{+}$ & - & -12 & $<1$ \\
\hline$i$-butane & 1 & $-5^{+}$ & 0 & $-4 * *$ & - & -21 & $4^{*}$ \\
\hline$n$-butane & $<1$ & $-2 *$ & $-6 * * *$ & $-4^{*}$ & - & -24 & $2 *$ \\
\hline$i$-pentane & $<1$ & $-4^{+}$ & $-8 * * *$ & $-5^{* * *}$ & $-4^{*}$ & -19 & $<-1$ \\
\hline$n$-pentane & $<1$ & -4 & $-2^{+}$ & 0 & - & -27 & -4 \\
\hline
\end{tabular}

$* * * 0.001, * * 0.01, * 0.05,{ }^{+} 0.1$ level of significance

To estimate long-term variation in hydrocarbon data the non-parametric Mann-Kendall test was used to test for the existence of a trend (Gilbert, 1987; Salmi et al., 2002). The Mann-Kendall tests the null hypothesis of no trend against the alternative hypothesis that there is an increasing or decreasing monotonic trend as described by Salmi et al. (2002). Results of the Mann-Kendall test are shown in Table 2 and Fig. 4, where percentage change is the slope of the linear trend relative to the first year of measurements and is shown with other trend data from recent literature, in Table 2. We would like to note that this five year record is a rather short dataset from which to estimate long-term atmospheric trends however we have included these to enable initial comparison to other available datasets. Other studies have calculated long-term trends using ten year datasets and propose this to be the minimum length dataset over which one can verify a "long-term" trend (for example von Schneidemesser et al., 2010; Dollard et al., 2007; Hakola et al., 2006; Helmig et al., 2009).

Trends are compared with other data from literature in Table 2. Short term trends in Mace Head data from 2005 to 2009 are seen for $i$-butane and $n$-butane in European air masses with decreases of 5 and $2 \%$ per year respectively with 90 and $95 \%$ levels of significance. The pentanes both show decreases of $4 \%$ per year. These results are in agreement with regulations as the principle source of butanes and pentanes is from the evaporation of motor spirit which has been reduced in recent years due to the introduction of more efficient fuel canisters in motor vehicles (Dollard et al., 2007). As expected no significant trends are seen for ethane and propane which are primarily emitted from natural gas leakage and not from motor vehicles. A large reduction in the magnitude of downward trends for the hydrocarbons can be seen in the Mace Head dataset and also in other longer datasets (von Schneidemesser et al., 2010) from 2000 onwards. Data from von Schneidemesser et al., 2010 show reductions in NMHC mixing ratios from rural European sites of $2-8 \% \mathrm{yr}^{-1}$ from 1998 to 2008 . These data act to verify
Table 3. Rate coefficients and atmospheric lifetimes with respect to $\mathrm{OH}$ reactivity for a range of NMHCs where $[\mathrm{OH}]$ is $1.5 \times 10^{6}$ molec cm $^{-3}$.

\begin{tabular}{lcrr}
\hline & $\begin{array}{c}\mathrm{k}_{\mathrm{OH}} \\
\mathrm{cm}^{3} \mathrm{molec}^{-1} \mathrm{~s}^{-1}\end{array}$ & $\begin{array}{r}\tau_{\mathrm{OH}} \\
\text { hours }\end{array}$ & $\begin{array}{r}\tau_{\mathrm{OH}} \\
\text { days }\end{array}$ \\
\hline ethane & $2.40 \times 10^{-13 \mathrm{a}}$ & 771.6 & 32.2 \\
propane & $1.10 \times 10^{-12 \mathrm{a}}$ & 168.4 & 7.0 \\
$i$-butane & $2.12 \times 10^{-12 \mathrm{~b}}$ & 87.4 & 3.6 \\
$n$-butane & $2.30 \times 10^{-12 \mathrm{a}}$ & 80.5 & 3.4 \\
$i$-pentane & $3.60 \times 10^{-12 \mathrm{~b}}$ & 51.4 & 2.1 \\
$n$-pentane & $3.80 \times 10^{-12 \mathrm{~b}}$ & 48.7 & 2.0 \\
\hline
\end{tabular}

a Atkinson et al. (2006); ${ }^{b}$ Atkinson (2003)

to small downward trend seen from Mace Head data taken during European pollution events from 2005 to 2009.

We note that monthly averaged baseline data showed elevations of ethane, propane, the butanes and the pentanes from January until June of 2008. However, these elevations were not found to be statistically significant thus further work was not carried out into the source of this anomaly.

\subsection{Seasonal cycles}

Seasonal cycles of $\mathrm{C}_{2}-\mathrm{C}_{5}$ alkanes can be seen in Figs. 3 and 5. Maximum concentrations are observed in January and February and minima for slowly reacting compounds in July. More reactive compounds (butanes and pentanes) show a much broader summer minima from June right through to September in many cases. Ethane shows the most pronounced seasonal cycle followed by propane, $n$-butane and $i$-butane. Variation in the amplitude of seasonal cycles occurs due to differing reactivity of hydrocarbon species. Table 3 displays the rates of reaction and atmospheric lifetimes $(\tau)$ of a range of VOCs in relation to the hydroxyl $(\mathrm{OH})$ radical. NMHC's reaction with $\mathrm{OH}$ acts as the primary controller 

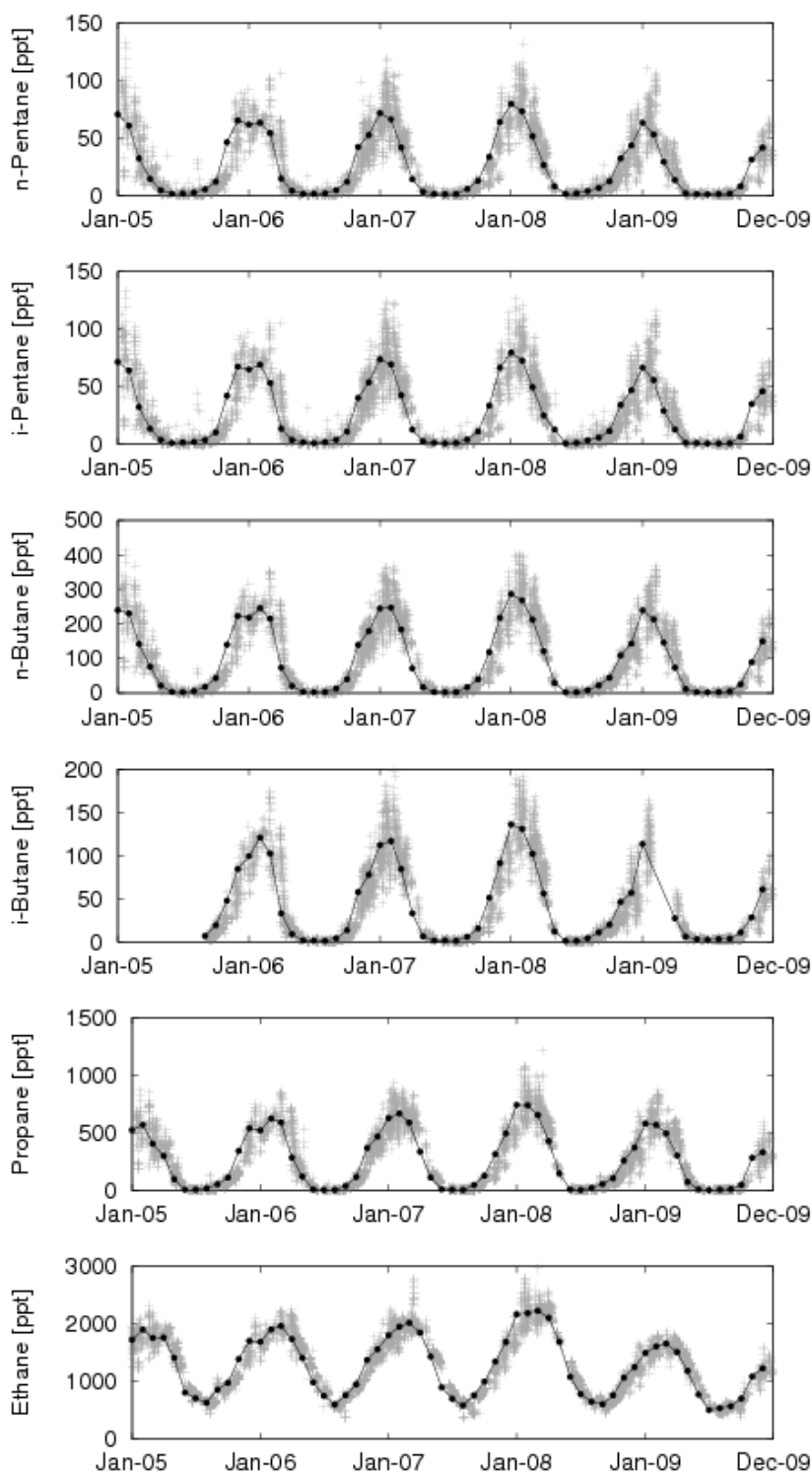

Fig. 3. Baseline data for $\mathrm{C}_{2}-\mathrm{C}_{5}$ alkanes from January 2005 until December 2009 with monthly averaged data overlaid in black.

of seasonal cycles, determining both their amplitude and distribution (Derwent et al., 2000). High $\mathrm{OH}$ levels in the summer results in increased removal of these compounds by $\mathrm{OH}$ oxidation. The prevailing westerly winds at Mace Head bring clean background air which has not encountered anthropogenic emissions in the previous 12 days, accounting for baseline Northern Hemispheric mole fractions. Air from southerly latitudes is depleted in ethane and propane due to increased mole fractions of the $\mathrm{OH}$ radical (from increased photolysis) at southerly latitudes which removes hydrocarbon species. European pollution events are marked by a sharp rise in hydrocarbon mole fractions from baseline values due to recent anthropogenic emissions.
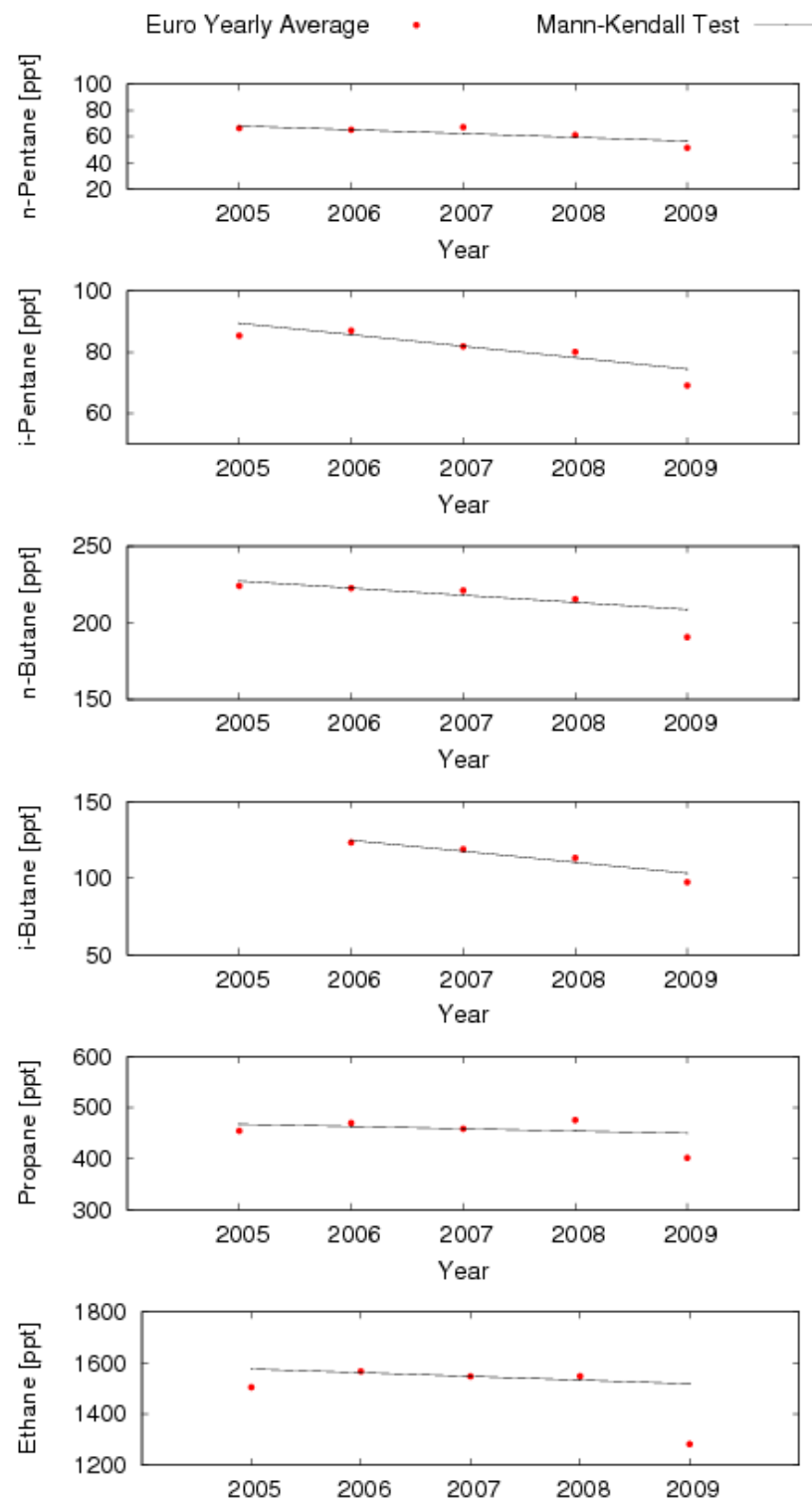

Fig. 4. Yearly averaged data from European air masses arriving at Mace Head (red circles) with the line computed from use of the Mann-Kendall test for the presence of significant trend.

\subsection{Literature comparison}

Table 4 shows seasonal cycle maxima and minima for hydrocarbon species measured at Mace Head. Hydrocarbon data from other remote Northern Hemispheric background sites are sparse. A Finnish study reported measurements of a range of NMHCs from a maritime site, Pallas, in the subarctic (Hakola et al., 2006). This site primarily receives clean air from the north and west where winter maxima and summer minima values are used for comparison in Table 4. Winter maxima values are always lower at Mace Head than at Pallas. The higher latitude of Pallas means it consequently receives many fewer hours of sunlight in winter months thus 
Table 4. Monthly average NMHC mole fractions for yearly maxima and yearly minima (in ppt) at Mace Head during the arrival of baseline northern hemispheric air masses with NMHC measurements from other remote northern hemispheric stations.

\begin{tabular}{|c|c|c|c|c|c|c|c|c|}
\hline & \multicolumn{3}{|c|}{ Winter Maximum (ppt) } & \multicolumn{5}{|c|}{ Summer Minimum (ppt) } \\
\hline & $\begin{array}{c}\text { This study } \\
\text { 2005-2009 } \\
\text { Baseline NH }\end{array}$ & $\begin{array}{c}\text { Hakola et al. (2006) } \\
\text { 1994-2003 } \\
\text { Pallas Subarctic }\end{array}$ & $\begin{array}{c}\text { This study } \\
\text { 2005-2009 } \\
\text { European }\end{array}$ & $\begin{array}{c}\text { This study } \\
\text { 2005-2009 } \\
\text { Baseline NH }\end{array}$ & $\begin{array}{c}\text { Lewis et al. (1997) } \\
1996 \\
\text { Baseline NH }\end{array}$ & $\begin{array}{c}\text { Hopkins et al. (2002) } \\
1999 \\
\text { Arctic cruise }\end{array}$ & $\begin{array}{c}\text { Hakola et al. (2006) } \\
\text { 1994-2003 } \\
\text { Pallas Subarctic }\end{array}$ & $\begin{array}{c}\text { This study } \\
2005-2009 \\
\text { European }\end{array}$ \\
\hline Ethane & 1928 & 2500 & 2289 & 604 & 558 & 442 & 750 & 729 \\
\hline Propane & 635 & 1300 & 962 & 6.5 & 143 & 56 & 100 & 86 \\
\hline$i$-Butane & 123 & 300 & 238 & 3.5 & 23.6 & 13 & 8 & 20 \\
\hline$n$-Butane & 246 & 590 & 429 & 3.0 & & 10 & 100 & 43 \\
\hline$i$-Pentane & 71 & 220 & 158 & 3.0 & 2.9 & & 20 & 17 \\
\hline$n$-Pentane & 69 & 150 & 125 & 2.0 & 5.3 & & 20 & 14 \\
\hline
\end{tabular}

Table 5. Yearly and overall averages of hydrocarbon data (in ppt) split into sectors of baseline air, European and southerly transported air masses.

\begin{tabular}{|c|c|c|c|c|c|c|c|c|c|}
\hline \multirow[t]{2}{*}{ Species } & \multicolumn{2}{|c|}{2005} & \multicolumn{2}{|c|}{2006} & & \multicolumn{2}{|c|}{2007} & \multicolumn{2}{|c|}{2008} \\
\hline & Baseline & European & Base & Euro & & Base & Euro & Base & Euro \\
\hline Ethane & $1549 \pm 307$ & $1306 \pm 125$ & $1576 \pm 297$ & $1310 \pm 118$ & & $1567 \pm 257$ & $1338 \pm 115$ & $1548 \pm 318$ & $1383 \pm 124$ \\
\hline Propane & $475.7 \pm 226.6$ & $249.2 \pm 69.0$ & $488.2 \pm 213.8$ & $263.6 \pm 72.4$ & & $470.1 \pm 176.6$ & $279.3 \pm 56.9$ & $458.9 \pm 183.2$ & $296.4 \pm 70.5$ \\
\hline$i$-Butane & $113.6 \pm 72.0$ & - & - & $44.2 \pm 12.3$ & & $123.8 \pm 62.4$ & $43.9 \pm 11.3$ & $119.6 \pm 64.2$ & $48.7 \pm 14.4$ \\
\hline$n$-Butane & $215.4 \pm 121.0$ & $95.8 \pm 30.7$ & $240.6 \pm 134.2$ & $96.4 \pm 25.1$ & & $222.6 \pm 102.8$ & $97.4 \pm 24.8$ & $221.1 \pm 112.2$ & $104.4 \pm 30.5$ \\
\hline$i$-Pentane & $80.4 \pm 52.7$ & $26.9 \pm 10.8$ & $91.8 \pm 66.4$ & $27.2 \pm 8.8$ & & $87.0 \pm 47.1$ & $27.2 \pm 8.6$ & $82.1 \pm 50.3$ & $29.2 \pm 11.8$ \\
\hline$n$-Pentane & $61.1 \pm 35.4$ & $26.6 \pm 9.9$ & $71.2 \pm 44.9$ & $26.5 \pm 8.1$ & & $65.2 \pm 33.3$ & $26.7 \pm 7.8$ & $67.1 \pm 35.0$ & $28.6 \pm 10.0$ \\
\hline \multirow[t]{2}{*}{ Species } & \multicolumn{2}{|c|}{2009} & \multicolumn{3}{|c|}{ Overall (2005-2009) } & Sauvage et al. (2009) & Dollard et al. (2007) & & \\
\hline & Base & Euro & Base & Euro & South & West Coast France & Rural UK & & \\
\hline Ethane & $1075 \pm 867$ & $1332 \pm 231$ & 1282 & 1490 & 1092 & 1756 & 1871 & & \\
\hline Propane & $227.4 \pm 57.9$ & $430.6 \pm 182.7$ & 263 & 452 & 223 & 731 & 832 & & \\
\hline$i$-Butane & $40.1 \pm 7.8$ & $82.1 \pm 48.0$ & 44 & 113 & 42 & - & 376 & & \\
\hline$n$-Butane & $80.3 \pm 24.7$ & $204.1 \pm 105.8$ & 95 & 215 & 90 & 294 & 505 & & \\
\hline$i$-Pentane & $22.1 \pm 8.1$ & $73.9 \pm 43.5$ & 26 & 81 & 34 & 205 & 407 & & \\
\hline$n$-Pentane & $20.9 \pm 7.4$ & $54.8 \pm 29.0$ & 26 & 62 & 26 & 177 & 102 & & \\
\hline
\end{tabular}

reducing removal by $\mathrm{OH}$ oxidation and photolysis compared with Mace Head. Summer minima show significant variation between baseline and European air masses as well as other European stations. Other data included in Table 4 comes from a maritime cruise which took place in the Arctic in August, 1999 (Hopkins et al., 2002). These data have been filtered to include only air masses which have not passed over land for at least 5 days prior to sampling. Hydrocarbon measurements made at Mace Head during a summer campaign in 1996 included in Table 4 have been filtered to only include measurements from the baseline south-westerly sector (Lewis et al., 1997). For the same site measurements made by Lewis et al. (1997) show reasonable similarity for the pentanes with differences of $<4$ ppt. Large differences are seen between summer minimum propane at Mace Head (6.5 ppt) and the summer minimum values recorded at other stations. Propane measurements of 143 ppt are reported by Lewis et al. (1997) in August 1996. These may be higher due to weather conditions (possible cooler or less sunny days) experienced during the campaign. Summer minimum propane of $56 \mathrm{ppt}$ is reported from the Arctic cruise and $100 \mathrm{ppt}$ propane is reported by the clean maritime subarctic site, Pallas in Finland. Both measurements are higher than Mace Head as expected due to lower $\mathrm{OH}$ radical concentrations at higher latitudes (Hakola et al., 2006). Interestingly the Arctic cruise shows lower ethane values but higher mole fractions of all other NMHCs measured. The difference in propane values measured at other sites during earlier time periods may be explained if one takes into account changes in motor vehicle emissions. Dollard et al. (2007) highlighted that propane emissions from motor vehicles was being steadily reduced due to the large scale implementation of catalytic converters, which now exist in the large majority of motor vehicles. The main source of propane is from natural gas leakage. However, this source is relatively constant and therefore the reduction or removal of propane emissions from motor vehicles would explain why baseline Mace Head summer minima measured from 2005 to 2009 are lower than all other European propane measurements which were made before 2005 prior to reductions in motor vehicle propane emissions.

Hydrocarbon mole fractions measured at Mace Head in European air masses were found to be elevated significantly 

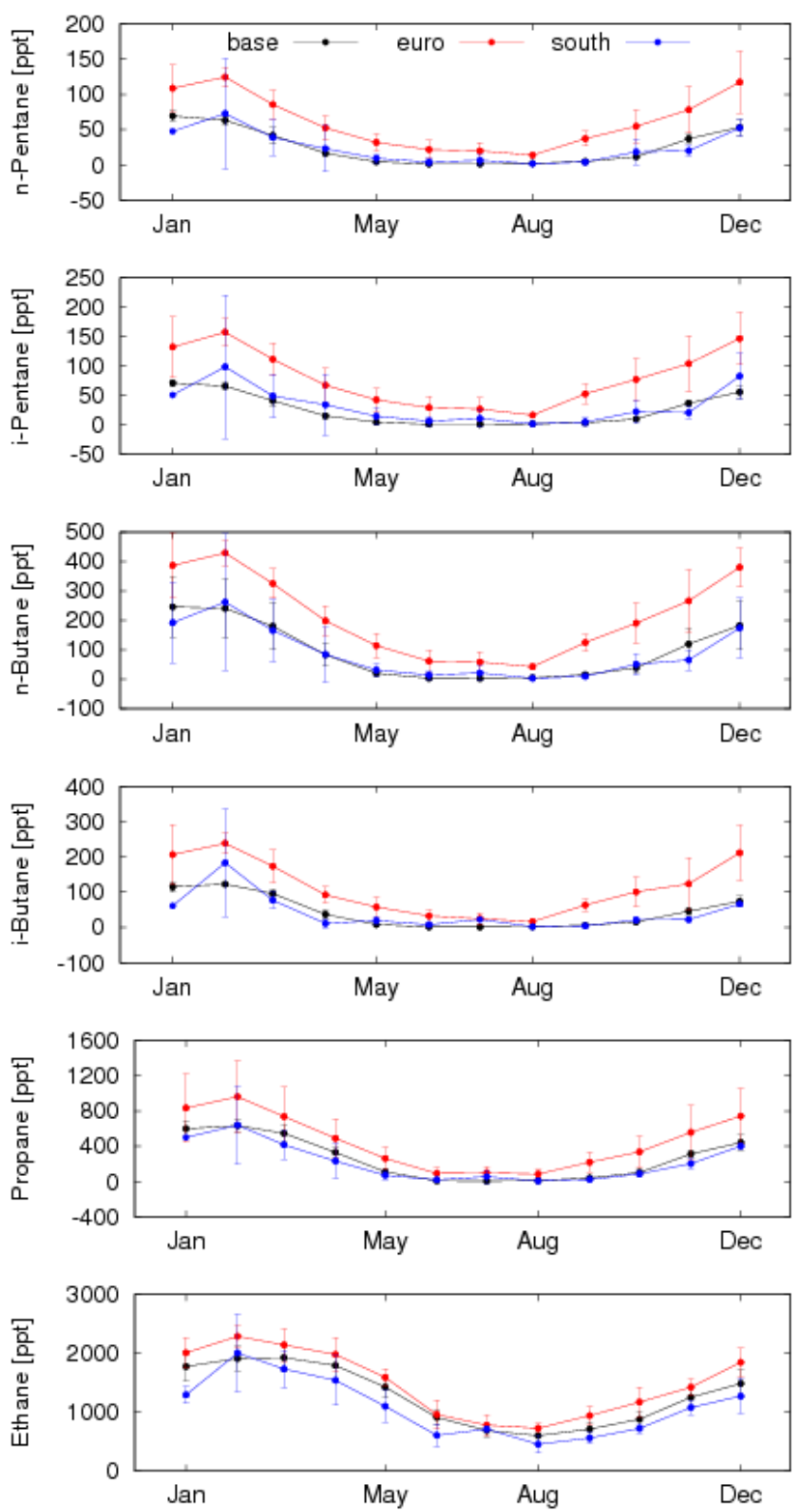

Fig. 5. Monthly averaged data over the five year period from 20052009 separated into baseline (black), European (red) and southerly transported (blue) air masses with error bars as $1 \sigma$.

from baseline air masses. Annual averages showed minimum elevations of $36 \mathrm{ppt}$ for $n$-pentane and maximum elevations of $200 \mathrm{ppt}$ for ethane (Table 5). Seasonal variations were found to be much higher where European winter maxima were elevated compared to baseline seasonal cycles by $>300 \mathrm{ppt}$ for ethane and propane, and by $>100 \mathrm{ppt}$ for the butanes (Table 4). Differences between European and baseline summer minima were much smaller. This is due to increased species loss in the summer months due to elevated levels of The $\mathrm{OH}$ radical. Largest differences between baseline and European summer minima were seen for propane
(73 ppt), followed by ethane (49 ppt) with $i$-butane and showing differences of $<20$ ppt.

Table 5 shows yearly average mole fractions in baseline and European air masses of the range of compounds measured at Mace Head compared with other measurements made at Mace Head and in Europe. All species reported in the rural UK site by Dollard et al. (2007) are higher than Mace Head averages due to the influence of anthropogenic emissions in the UK. Data from a maritime site on the west coast of France (Sauvage et al., 2009) are always higher than Mace Head data and lower than rural UK data.

\section{Summary}

A five year record of high-frequency in situ measurements of NMHCs measured at Mace Head, a background Northern Hemispheric station, was analysed. These data were separated into their air mass origins of baseline, European polluted and southerly transported using a Lagrangian dispersion model. Hydrocarbon mole fractions were elevated in European air masses for all species. Baseline air masses which have been transported across the north Atlantic showed the most stable mole fractions. Southerly transported air masses showed significant depletions in $\mathrm{C}_{2}-\mathrm{C}_{4}$ alkanes resulting from high $\mathrm{OH}$ at low latitudes. Summer minima occurred in July and winter maxima in January/February for all species. Shorter lived species, showed a prolonged summer minima which sometimes lasted for four months.

Long-term trends in Northern Hemispheric baseline air were assessed by use of the Mann-Kendall test. No statistically significant trends were observed in baseline air masses over the five year period (2005-2009). European air masses were found to have statistically significant downward trends of $i$ and $n$-butane and $i$-pentane of 5, 2 and $4 \%$ per year, respectively. Baseline air masses in early 2008 were found to have elevated levels of $\mathrm{C}_{2}-\mathrm{C}_{5}$ alkanes, however this elevation was found to be statistically insignificant.

Acknowledgements. We specifically acknowledge the cooperation and efforts of the station operators Gerry Spain and Duncan Brown at Mace Head monitoring station. We also thank the Physics Department, National University of Ireland, Galway, for making the research facilities at Mace Head available. The operation of the AGAGE station at Mace Head was funded by the Department of the Environment, Food and Rural Affairs (DEFRA) (contracts PECD 1/1/130 and 7/10/154, EPG 1/1/82 and EPG 1/1/130 to International Science Consultants, CPEG 27 and GA0201 to the UK Met. Office and GA01081 to the University of Bristol); and the Department of Energy and Climate Change (DECC) through contract GA01103.

Edited by: D. Heard 


\section{References}

Atkinson, R.: Kinetics of the gas-phase reactions of $\mathrm{OH}$ radicals with alkanes and cycloalkanes, Atmos. Chem. Phys., 3, 22332307, doi:10.5194/acp-3-2233-2003, 2003.

Atkinson, R., Baulch, D. L., Cox, R. A., Crowley, J. N., Hampson, R. F., Hynes, R. G., Jenkin, M. E., Rossi, M. J., Troe, J., and IUPAC Subcommittee: Evaluated kinetic and photochemical data for atmospheric chemistry: Volume II - gas phase reactions of organic species, Atmos. Chem. Phys., 6, 3625-4055, doi:10.5194/acp-6-3625-2006, 2006.

Boudries, H., Toupance, G., and Dutot, A. L.: Seasonal variation of atmospheric nonmethane hydrocarbons on the western coast of Brittany, France, Atmos. Environ., 28, 1095-1112, doi:10.1016/1352-2310(94)90287-9, 1994.

Cunnold, D. M., Weiss, R. F., Prinn, R. G., Hartley, D., Simmonds, P. G., Fraser, P. J., Miller, B., Alyea, F. N., and Porter, L.: GAGE/AGAGE measurements indicating reductions in global emissions of CCl3F and CCl2F2 in 1992-1994, J. Geophys. Res., 102, 1259, doi:1210.1029/1296JD02973, 1997.

Derwent, R. G., Davies, T. J., Delaney, M., Dollard, G. J., Field, R. A., Dumitrean, P., Nason, P. D., Jones, B. M. R., and Pepler, S. A.: Analysis and interpretation of the continuous hourly monitoring data for $26 \mathrm{C} 2-\mathrm{C} 8$ hydrocarbons at 12 United Kingdom sites during 1996, Atmos. Environ., 34, 297-312, 2000.

Derwent, R. G., Jenkin, M. E., Saunders, S. M., Pilling, M. J., Simmonds, P. G., Passant, N. R., Dollard, G. J., Dumitrean, P., and Kent, A.: Photochemical ozone formation in north west Europe and its control, Atmos. Environ., 37, 1983-1991, doi:10.1016/s1352-2310(03)00031-1, 2003.

Dimmer, C. H., Simmonds, P. G., Nickless, G., and Bassford, M. R.: Biogenic fluxes of halomethanes from Irish peatland ecosystems, Atmos. Environ., 35, 321-330, 2001.

Dollard, G. J., Dumitrean, P., Telling, S., Dixon, J., and Derwent, R. G.: Observed trends in ambient concentrations of C2-C8 hydrocarbons in the United Kingdom over the period from 1993 to 2004, Atmos. Environ., 41, 2559-2569, 2007.

Dore, C. J., Watterson, J. D., Murrells, T. P., Passant, N. R., Hobson, M. M., Baggott, S. L., Thistlewaite, G., J. W. L., G., King, K. R., Adams, M., Walker, C., Downes, M. K., Cloeman, P. J., Stewart, R. A., Wagner, A., Sturman, J., Conolly, C., Lawrence, H., Jackson, J., Li, Y., Bush, T., Grice, S., and Brophy, N.: UK Emissions of Air Pollutants 1970 to 2005, AEA Energy and Environment, 2007.

Gilbert, R. O.: Statistical methods for environmental pollution monitoring, Van Nostrand Reinhold, New York, 1987.

Haagen-Smit, A. J. and Fox, M. M.: Ozone formation in Photochemical Oxidation of Organic Substances, Ind. Eng. Chem., 48, 1484-1487, 1956.

Hakola, H., Hellén, H., and Laurila, T.: Ten years of light hydrocarbons (C2-C6) concentration measurements in background air in Finland, Atmos. Environ., 40, 3621-3630, doi:10.1016/j.atmosenv.2005.08.019, 2006.

Helmig, D., Bottenheim, J., Galbally, I. E., Lewis, A. C., Milton, M. J. T., Penkett, S. A., Plass-Duelmer, C., Reimann, S., Tans, P., and Thiel, S.: Volatile organic compounds in the global atmosphere, EOS Trans., AGU, 90, 513-520, 2009.

Hopkins, J. R., Jones, I. D., Lewis, A. C., McQuaid, J. B., and Seakins, P. W.: Non-methane hydrocarbons in the Arctic boundary layer, Atmos. Environ., 36, 3217-3229, doi:10.1016/s1352-
2310(02)00324-2, 2002.

Jones, A. R., Thomson, D. J., Hort, M., and Devenish, B.:

The U.K. Met Office's next-generation atmospheric dispersion model, NAME III, in Borrego C. and Norman A.-L. (Eds), Air Pollution Modeling and its Application XVII Proceedings of the 27th NATO/CCMS International Technical Meeting on Air Pollution Modelling and its Application, 580-589, 2007,

Lewis, A. C., Bartle, K. D., Heard, D. E., McQuaid, J. B., Pilling, M. J., and Seakins, P. W.: Insitu, gas chromatographic measurements of non-methane hydrocarbons and dimethyl sulfide at a remote coastal location (Mace Head, Eire) July-August 1996, J. Chem. Soc., Faraday Transactions, 93, 2921-2927, 1997.

Manning, A. J., O’Doherty, S., Jones, A. R., Simmonds, P. G., and Derwent, R. G.: Estimating UK methane and nitrous oxide emissions from 1990 to 2007 using an inversion modeling approach, J. Geophys. Res., 116, D02305, doi:10.1029/2010jd014763, 2011.

Miller, B. R., Weiss, R. F., Salameh, P. K., Tanhua, T., Greally, B. R., Muhle, J., and Simmonds, P. G.: Medusa: A Sample Preconcentration and GC/MS Detector System for in Situ Measurements of Atmospheric Trace Halocarbons, Hydrocarbons, and Sulfur Compounds, Anal. Chem., 80, 1536-1545, 2008.

Mühle, J., Lueker, T. J., Su, Y., Miller, B. R., Prather, K. A., and Weiss, R. F.: Trace gas and particulate emissions from the 2003 southern California wildfires., J. Geophys. Res, 112, D03307, doi:10.1029/2006JD007350, 2007.

O’Doherty, S., Cunnold, D. M., Manning, A., Miller, B. R., Wang, R. H. J., Krummel, P. B., Fraser, P. J., Simmonds, P. G., McCulloch, A., Weiss, R. F., Salameh, P., Porter, L. W., Prinn, R. G., Huang, J., Sturrock, G., Ryall, D., Derwent, R. G., and Montzka, S. A.: Rapid growth of hydrofluorocarbon 134a and hydrochlorofluorocarbons 141b, 142b, and 22 from Advanced Global Atmospheric Gases Experiment (AGAGE) observations at Cape Grim, Tasmania, and Mace Head, Ireland, J. Geophys. Res., 109, D06310, doi:10.1029/2003JD004277, 2004.

Oltmans, S. J., Lefohn, A. S., Harris, J. M., Galbally, I., Scheel, H. E., Bodeker, G., Brunke, E., Claude, H., Tarasick, D., Johnson, B. J., Simmonds, P., Shadwick, D., Anlauf, K., Hayden, K., Schmidlin, F., Fujimoto, T., Akagi, K., Meyer, C., Nichol, S., Davies, J., Redondas, A., and Cuevas, E.: Long-term changes in tropospheric ozone, Atmos. Environ., 40, 3156-3173, doi:10.1016/j.atmosenv.2006.01.029, 2006.

Prinn, R. G., Weiss, R. F., Fraser, P. J., Simmonds, P. G., Cunnold, D. M., Alyea, F. N., O’Doherty, S., Salameh, P., Miller, B. R., Huang, J., Wang, R. H. J., Hartley, D. E., Harth, C., Steele, L. P., Sturrock, G., Midgley, P. M., and McCulloch, A.: A history of chemically and radiatively important gases in air deduced from ALE/GAGE/AGAGE, J. Geophys. Res., 105, D14, doi:10.1029/2000JD900141, 2000.

Ryall, D. B. and Maryon, R. H.: Validation of the UK Met Office's NAME model against the ETEX dataset, Atmos. Environ., 32, 4265-4276, 1998.

Salmi, T., Maatta, A., Anttila, P., Ruoho-Airola, T., and Amnell, T.: Detecting trends of Annual values of atmospheric pollutants by the Mann-Kendall test and Sen's slope estimates - The Excel template application Makesens, Helsinki: Finnish Meteorological Institute, Publications on air quality, 2002.

Sauvage, S., Plaisance, H., Locoge, N., Wroblewski, A., Coddeville, P., and Galloo, J. C.: Long term measurement 
and source apportionment of non-methane hydrocarbons in three French rural areas, Atmos. Environ., 43, 2430-2441, doi:10.1016/j.atmosenv.2009.02.001, 2009.

Simmonds, P. G., Derwent, R. G., Manning, A. L., and Spain, G.: Significant growth in surface ozone at Mace Head, Ireland, 19872003, Atmos. Environ., 38, 4769-4778, 2004.

Solberg, S., Dye, C., Schmidbauer, N., Wallasch, N., and Junek, R.: VOC measurements 2000, EMEP/CCC Report 8/2002, 2002. von Schneidemesser, E., Monks, P. S., and Plass-Duelmer, C.: Global comparison of VOC and $\mathrm{CO}$ observations in urban areas, Atmos. Environ., 44, 5053-5064, doi:10.1016/j.atmosenv.2010.09.010, 2010.

Yates, E. L., Derwent, R. G., Simmonds, P. G., Greally, B. R., O'Doherty, S., and Shallcross, D. E.: The seasonal cycles and photochemistry of C2-C5 alkanes at Mace Head, Atmos. Environ., 44, 2705-2713, 2010. 